See discussions, stats, and author profiles for this publication at: https://www.researchgate.net/publication/338893010

\title{
Transparency Is (Full) Disclosure in Corporate Governance
}

Chapter · January 2020

DOI: 10.1007/978-3-030-35780-1_3

CITATIONS

0

3 authors:

Finn Janning

None

21 PUBLICATIONS 20 CITATIONS

SEE PROFILE

tce Coral Ingley

Auckland University of Technology

42 PUBLICATIONS 1,197 CITATIONS

SEE PROFILE
READS

971

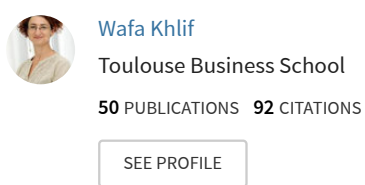

Some of the authors of this publication are also working on these related projects:

SME Governance View project

Project Les obligations à impact social arrivent en France : l'action sociale peut-elle être rentable ? View project 
The Illusion of

Transparency in

Corporate

Governance

Does Transparency

Help or Hinder True

Ethical Conduct?

Free

Preview

\section{The Illusion of Transparency in}

Corporate Governance Does Transparency Help or Hinder True Ethical Conduct?

Authors: Janning, Finn, Khlif, Wafa, Ingley, Coral

Provides an innovative, critical perspective on transparency for the corporate governance field, highlighting an emerging area

Uses philosophical concepts and understandings to stimulate new thinking about corporate governance, encouraging regulators to question their requirements for good corporate governance practice

Addresses the shift in societal expectations for ethical behaviour 


\section{Table of contents $(5$ chapters)}

Framing Transparency

Janning, Finn (et al.)

Preview

Transparency: A Moral Concept

Janning, Finn (et al.)

\section{Preview}

Transparency Is (Full) Disclosure in Corporate Governanct Janning, Finn (et al.)

Preview

Transparency a Paradoxical Proxy for Trust?

Janning, Finn (et al.)

Preview

Transparency: A False Solution to a Real Problem Janning, Finn (et al.) 


\title{
Chapter 3. Transparency is (full) disclosure in corporate governance
}

\begin{abstract}
Corporate disclosure and reporting of information has become synonymous with transparency which in discourses idealising its value is part of the rhetoric of good governance. This notion is overtly conveyed in principles and codes of corporate governance practice which have proliferated globally over the last three decades. The possibility for transparency to conceal more than is revealed is considered with regard to corporate communication of information, with the consequence that power and real knowledge of the corporate behavioural agenda remains in corporate hands. Philosophically, the paradoxical and unintended outcome is that corporations are constrained by the norm of transparency in developing authentic moral behaviour, while also exercising power and control since in the information society transparency does not, and indeed cannot, lead to revealing all. Transparency places greater emphasis on judging, or evaluating existing organisational processes than on assessment of (self-)learning processes based on what actually takes place when corporations make decisions.
\end{abstract}

Keywords

Codes, corporate governance, disclosure, new transparency, power, CSR.

In various codes and regulations, transparency appears as one of the four pillars in corporate governance, together with accountability, responsibility and fairness. As such, both international and local institutions advocate transparency and sometimes impose it as representing clear evidence of good corporate governance practice.

It is assumed that being morally good by being transparent correlates with being trustworthy (Schnackenberg and Tomlinson, 2016). Baume and Papadopoulos (2018) counter this widely held view, stating that while there is growing enthusiasm for transparency in public affairs and discourses idealising its value, and it is part of the rhetoric used by advocates of "good governance", there is little justification for this fervour. The view that transparency underpins legitimacy and that it has virtuous effects is qualified by criticisms in scholarly work which emphasise the possible costs and perverse effects of the search for transparency, or that it may fail to deliver the expected benefits. What, then, is actually desired to encourage greater trust and responsibility? Is greater trust what is really being sought through calls for, and a fixation on, transparency?

In this chapter, we attempt to unravel the considerable confusion that clearly exists around such concepts - for which transparency seems to act as a proxy - in the quest to understand 
what is really required for better moral behaviour from organisations. We explore transparency in the context of moral obligation, as part of the corporate obligation of fiduciary duty. The moral problem emerges when corporations are motivated only to fit the expected social norms of disclosure that treat transparency as a way of endeavouring to increase systemic trust by meeting minimal standards set by laws and rules. Baume and Papadopoulos (2018) argue that the causal relationship between transparency and moralisation should not be posited in overly mechanistic terms: transparency is not a sufficient condition for moralisation which necessitates other prerequisites. In this way, corporate decisions and actions simply are legitimated rather than scrutinized (Christensen and Cornelissen, 2015). Instead of merely confirming that being transparent is what a corporation ought to do, a closer scrutiny might provoke questions such as "What might also be possible? - "What else can be done?" - "What might be done instead?" In this chapter we show that calling for honesty and trust is neither the same as - nor is it aligned, philosophically, with - calling for transparency.

\section{Transparency in principles and codes of "good" governance practice}

While the quest for transparency emerged in political discourse in the late eighteenth century, the current widespread use of transparency is linked to, and grounded in, an economics literature (as part of agency theory and a game-theoretic logic) that is concerned with lowering transaction costs, improving market information and increasing organisational efficiency (Albu and Flyverbom, 2019; Baume and Papadopoulos, 2018). Schnackenberg and Tomlinson (2016) observed that transparency is often invoked as a balm for corporate malfeasance through its presumed ability to restore stakeholder trust in the firm and in the financial market system. In this way, transparency is seen as the answer because it lifts the veil of corporate secrecy (Albu and Flyverbom, 2019). Baume and Papadopoulos noted that in the research and debate on the causes of, and remedies for, corruption the purifying power of transparency is a well-established assumption.

Transparency is valued as a fundamentally positive feature of relationships because the disclosure of information is believed to facilitate (systemic) trust (Albu and Flyverbom, 2019), although this represents a narrow focus on information and quality. Transparency is also considered a standard for achieving systemic trust since it is said to open professional practices to public scrutiny. Transparency norms and regulations are enforced by 
transnational bodies (e.g., the EU Non-Financial Reporting Directive, 2013) and in egovernment.

ECB drama highlights the central bank transparency dilemma

Michael McMahon, The Conversation, 6 June 2014

"When the European Central Bank sent markets reeling yesterday with moves designed to stimulate growth, the 24 people who made that decision could remain comfortable that their exact arguments and misgivings expressed prior to the final decision would be shielded from public view. The broader trend though is to bring the workings of monetary policy out of the shadows, and that means a tricky job to balance a quest for transparency at central banks with a desire for frank and open discussion.

Mario Draghi, ECB President, has spoken of the desirability of "a richer communication about the rationale behind the decisions that the governing council takes". Moreover, in April, the Bank of England announced that they would conduct a review of the costs and benefits of releasing transcripts of the MPC meetings... But it is harder than you might think to work out what the best disclosure policy might be. The Bank of England review will look at what the effects might be of greater transparency. In particular, given that deliberation takes up the vast majority of such committees' time, it is important to ask what the effect of greater transparency might be on how the committee members talk amongst themselves.

The main negative effect is that transparency will induce conformity amongst members and lead to a stifled, and potentially useless, debate... Fed chairman, Alan Greenspan, said of how the release of transcripts would affect the FOMC meeting: I fear in such a situation the public record would be a sterile set of bland pronouncements scarcely capturing the necessary debates which are required of monetary policymaking.

...Both the European banks will have to structure the deliberation process in way which maximises the discipline effect which increases the information at hand while minimising the conformity effect which can deaden debate."

https://theconversation.com/ecb-drama-highlights-the-central-bank-transparencydilemma-27351 (Accessed June 4 2019).

In business ethics, transparency is defined as an informational mechanism necessary for trust, justice, and prudence. The idea of transparency controls corporations as a form of "power that is created and sustained by their voluntary submission to it" (Newman 2017, p. 92). By being transparent, even when this is (mistakenly) based on the notion that more (i.e. full disclosure/transparency) is better (Schnackenberg and Tomlinson 2016; Christensen and Cheney, 2015), individuals and corporations may believe that they are doing good morally, although it is impossible to know what people or corporations really think, feel and do, or what the corporations or their stakeholders really want. 
Fung (2014, p. 72) stated that transparency "is taking on a new meaning of more comprehensive and proactive disclosures instead of the release of corporate governance details or policies, which it is doing in a 'reactive' fashion" (as in the Access Info Europe case at the end of Chapter 2). This type of disclosure is reactive in the sense that what is possible, morally, to improve on is limited by what the corporation's current reality is regarding its performance. This is epitomised by the auditors' certification of what represents a "true and fair view" - a version of "reality" that is established on the basis of what is already known and measurable according to agreed standard practices. In the previous chapter we introduced Deleuze and Guattari's (1987) rhizome concept as an alternative to the arborescent thinking that assumes a universal, fixed blueprint of how things should be. Instead of following an illusory blueprint which is closed to new possibilities and thus is self-limiting, we suggest that the concept of fairness be related to how auditors approach a world of differences. As Badiou (2002) emphasised, instead of believing in the existence one universal and unchangeable truth, ethical examination circles around the "unnameable": the latent, tacit, or innate - that which is real although not yet articulated or actualised. "To determine the unnameable point of a particular type of truth-process is a difficult task for (philosophical) thought", writes Badiou (p. 86), such that there are no grounds for sermonising and prescription. That is why humility in approach to what takes place matters, so that hubris and narcissism has no place in corporate leadership.

Transparency, leading to full disclosure as both action and behaviour, is understood in corporate governance as establishing standards of corporate ethics to deter unscrupulous corporate practices while preserving a fair business environment. Many practitioners, and some academics, especially in finance, use the terms "disclosure" and "transparency" interchangeably.

In the G20/OECD Principles of Corporate Governance (2015), Chapter V on "Disclosure and transparency" explicitly states in its preamble (p. 37) that "The corporate governance framework should ensure that timely and accurate disclosure is made on all material matters regarding the corporation, including the financial situation, performance, ownership, and governance of the company" ${ }^{11}$. When regulators require greater transparency from

\footnotetext{
${ }^{1}$ OECD (2015), G20/OECD Principles of Corporate Governance, OECD Publishing, Paris, http://dx.doi.org/10.1787/9789264236882-en
} 
corporations they are seeking, through more disclosure, greater honesty and trustworthiness in corporations, to build confidence and integrity in the capital markets. These are concepts that we elaborate on in the next chapter.

\section{Transparency is disclosure}

In corporate governance literature, numerous studies view disclosure (of information) as a key dimension of transparency (e.g., Bushman et al., 2004; Finel and Lord, 1999; Madhavan et al., 2005; Nicolaou and McKnight, 2006; Pagano and Roell, 1996). The relationship between transparency and information is better grasped by reference to the opposite of transparency: opacity, which is defined as "the state of being hard to understand, not clear or lucid. When information is not clear or hidden, it is not trusted" (Borgia, 2005, p. 22). Borgia declared that transparency leads to an endless cycle of information needs: "the more we know, the more we demand to know, the more there seems to be to disclose" (ibid.).

Several works define disclosure as the perception that relevant information is received in a timely manner (e.g., Bloomfield and O'Hara, 1999; Williams, 2008), or providing a fast, easy, and inexpensive means of obtaining feedback (Borgia, 2005). Specifically, transparency is associated with the need for stakeholders to have access to quality information to optimise their decisions (Braendle and Noll, 2005) and is linked to voluntary disclosure. Fabrizio and Kim (2017) found in the US context that financial intermediaries give better ratings to firms with voluntary disclosure of high quality information, especially for environmental outcomes. While this finding concurs with those of some studies (e.g. Griffin and Sun, 2013; Arsov and Bucevska, 2017), it contradicts others.

Shedding more light on the black box: the new auditor's report, Prof. Dr. rer. pol. Thomas Berndt, Disclose, Issue 1, 2017, PWC

"Sunlight is said to be the best of disinfectants. The belief that light - in other words transparency - is the best protection for participants in the capital markets has been one of the guiding principles of regulators for over a hundred years. Transparency is supposed to provide a better basis for investment decisions, discourage creative accounting practices and generally improve the functioning of the financial markets. In past years, this has prompted much more stringent requirements regarding the scope and detail of the information stock-exchange-listed companies have to disclose in their financial reporting." https://disclose.pwc.ch/25/media/pdf/pwc disclose 1701 e.pdf (Accessed May 25 2019). 
The economist Herbert Simon (1971) noted that when information becomes abundant, attention becomes the scarce resource. In an information-rich world, the wealth of information means a dearth of something else: a scarcity of whatever it is that information consumes - namely, the attention of its recipients. Hence a wealth of information creates a poverty of attention and a need to allocate that attention efficiently among the overabundance of information sources that might consume it. ${ }^{2}$

The question is whether being transparent is the best way of interpreting the information stimuli with which individuals are constantly bombarded. When stakeholders (and the public in general) are inundated with information it risks being ignored as merely "noise" when what is required is relevant information - about the company's performance. With the explosion in information technology the basic but underdeveloped capacity of paying attention to what is important is under pressure from information overload, which in the business context is likely to lead to a reduction in decision quality. Overload conditions are more likely to result in poorer, more impulsive or hasty decisions by executives and stakeholders alike, based on the information at hand rather than informed decisions for which time is needed to gather and process the necessary information.

Transparency based on information is associated with speediness and smoothness. Haste is closely tied to general inattention to what is happening and whether individuals learn from previous experiences or disregard them. In contrast, a desire for greater transparency implies a desire for increased consistency, attentiveness, and clarity of information exchanged between two parties (Pagano and Roell, 1996). Schnackenberg and Tomlinson (2016) argued that transparency represents the intentionality of a company to share information perceived to be of relevance and quality by all receivers. Transparency is considered as a critical element of knowledge sharing (Schnackenberg and Tomlinson, 2016). Farvaque et al. (2011) observed that while regulators encourage heavy disclosure academics warn of the likely high cost it imposes on a company. Farvaque et al. contended further that "disclosure can reduce actors' incentives to look for information about the firm, and therefore can lead to an illusion of (potentially destabilizing) knowledge" (p. 5).

\footnotetext{
${ }^{2}$ We do not regard attention solely as a resource: it is also closely related to experience, i.e., a way of attending reality, "an engagement" or "way of being". Attention is often coupled with awareness understood as "a complementary form of intelligence" where "we can hold our thoughts in awareness", which "gives us an entirely new perspective on them and their content" (Kabat-Zinn, 2013, p. xxxv).
} 
Sharing information is not the same as sharing knowledge, which is based on experience and takes time to develop. Knowledge building results from a process where received information is questioned and tested for its veracity and usefulness. Contiguously, there has been extensive debate in knowledge management theory as to how to make tacit knowledge more explicit, and therefore shareable (see Polanyi, 2009; Nonaka, 1994). To make what is tacit explicit, or to transform information into knowledge, time is needed. Nonetheless, the issue is whether transparency based on information, alone, however explicit it may be, is sufficient for generating true knowledge upon which to assess a corporation's moral intent and trustworthiness.

In Chapter 2 knowledge was explained as leading to understanding where, through a questioning approach to what is taken for granted, new transformative possibilities can emerge as pathways for behavioural change. If this space for thought or reflection is denied or non-existent, what remains is Han's (2018) terror of the same. He states that "In that hell of sameness, humans are nothing but remote-controlled puppets" (p. 9) As we have argued, the norm of transparency contrives in this way to place power not in the hands of stakeholders who wish to assess a corporation's trustworthiness. Instead power is concentrated and retained, whether in the hands of international organisations with their standards, or of the corporation itself according to what it chooses to disclose.

Reports on the Observance of Standards and Codes. The World Bank.

"Standards and codes are benchmarks of good practices. The Report on the Observance of Standards and Codes (ROSC) initiative was launched in 1999 as a prominent component of efforts to strengthen the international financial architecture. The initiative aims at promoting greater financial stability, both domestically and internationally, through the development, dissemination, adoption, and implementation of international standards and codes. The ROSC initiative is administered by the World Bank and International Monetary Fund (IMF), which have recognized international standards in 12 policy areas. The World Bank focuses on three of these:Accounting and Auditing; Corporate Governance; Insolvency and Creditor Rights. The 12 policy areas fall under one of three broader groups - policy transparency, financial sector regulation and supervision, and market infrastructure:

1) Policy Transparency

Standards in these areas have been developed by the IMF

- Data Dissemination

- Fiscal Policy Transparency

- Monetary and Financial Policy Transparency."

http://www.worldbank.org/en/programs/rosc (Access Apr 29 2019). 
Han's homogeneity leads to a metaphorical mute blindness in the face of a homogenised society where difference and diversity are removed. Similar to Tsoukas (1997), referred to at the end of the previous chapter, Han $(2015$, p. 8) further moots that "Transparency and truth are not identical. Truth is a negative force insofar as it presents and asserts itself by declaring all else false... Hyper-communication and hyper-information attest to the lack of truth - indeed to a lack of being. More information, or more communication, does not eliminate the fundamental absence of clarity for the whole. If anything, it heightens it" (p. 8). Tsoukas referred to this absence of clarity and lack of being as an inability to comprehend the complexity of the 'world' and what is going on. Thus we argue that transparency does not lead to better decisions based on interpreting information and that, alone, it does not produce true knowledge about, and hence understanding of, a corporation's intent and trustworthiness. Instead, as Borgia (2005) and Han (2015), have argued, transparency leads to the endless cycle of information needs which are more likely to lead to greater opacity.

\section{The "new" transparency}

Bandsuch et al. (2008) concur that no single element [such as transparency] is sufficient to meet all the goals or ensure all the benefits of effective corporate governance. They argue that when principle-centred leadership, transparency, stakeholder voice, and ethical culture are practiced simultaneously such that they are mutually reinforcing and are integrated into the various policies and practices of corporate governance, the resulting synergy has the potential to maximise the benefits of corporate governance. These benefits include the rebuilding of lost stakeholder trust in business, and avoiding actions that create the risk of additional damage to that trust. Bandsuch et al. posit that principle-centred leaders foster a trustful environment that facilitates transparency, both internal and external to the firm. In this way, transparency engenders (systemic) trust, reinforcing the ethical governance of the firm and the two are thus mutually reinforcing. They see transparency as a catalyst, strengthening the demand for greater openness and disclosure: it is not a programme or process but a dynamic imperative that moves transparency beyond the narrow, traditional realm of financial disclosure into the larger context of stakeholder communication and the interaction between corporate management and constituencies beyond the shareholder and 
prospective investor. As such, they say, this reinforces the ethics of the organisation. Bandsuch et al. term this approach the "new transparency".

Fernandez Feijo et al. (2014) claim that corporate social responsibility (CSR) reporting leads to a transparent image and reinforces the relationship between investors and the company. They found that pressure from some groups of stakeholders increases the quality of transparency of the reports. Doorey (2011) highlighted Nike and Levis-Strauss as "good examples" of those that play a central role in fostering supply chain transparency by disclosing lists of their suppliers. Graafland, et al. (2004, p. 137) stated that "the CSR of a company will only be correctly perceived by the public if its social and environmental value creation is transparent". Thus, the increasing demands for disclosure in all types of organisational reports (annual financial reports, CSR, sustainability, and suchlike) reflect stakeholder expectations for a certain level of transparency (Dickson and Eckman, 2008; Frostenson et al., 2011; Halter, et al., 2009). Such disclosure underscores what Han (2015) regarded as being akin to pornography in a transparent society, where only by exhibiting everything can the value of transparency be shown. Accordingly, transparency can become a narcissistic exercise for corporations that fall in love with their reputational image. Parsons (2019) analyses "transparency reports" in "promoting change in firm and government behaviour" (p. 103). He concludes that these reports may become more comparable to each other over time, adjusting ultimately to a standard. This specific standard or norm will generally result from a crisis (usually local) that has led the government or industry to adopt it. Parsons also notes that such norms are random regarding the results they have on firms' behaviour, such results being neither consistent nor convergent.

Regardless of the extent to which examples of "good" corporate behaviour might motivate better behaviour in others, isomorphism may lead to pressure on corporations to share information for the sake of being seen to be transparent. The "good" examples might also be offset by actions that are to the contrary. A hypothetical example could be that of a corporation which might suggest car-sharing for its employees, thereby demonstrating good behaviour in lowering pollution. However, if the work done by the corporation is questionable regarding employment practices or the products produced, then what of the exemplary nonpollution behaviour? Or a corporation might provide all of its employees with a bicycle to use as transport to and from work, but the good represented by a clean form of transportation 
might by negated if additional commuting time means that more hours are spent away from family. Examples such as this, while hypothetical, nevertheless represent real potential situations where deliberative thought is required to consider all possible consequences so as to ensure an appropriate outcome for truly moral behaviour.

In the field of CSR, transparency is predominantly conceptualised as strategic information disclosure that generates organisational legitimacy and eliminates corruption. Leadership studies similarly link transparency to trust among followers. Management practitioners advocate transparency as a tool for reputation management and a way to demonstrate trustworthiness (Albu and Flyverbom, 2019). However, with these conceptualisations a moral problem arises concerning what can be shared openly if, ontologically, what is not being shared is seemingly non-existent. As we contended earlier, if full transparency is about sharing everything openly, then anything not shared either cannot exist, or it is not completely transparent and is therefore secret (Christensen and Cornelissen, 2015). Hence such ontological and epistemological questions touch upon the morality of disclosure and nondisclosure where the act of being transparent can be seen as the corporation's capacity to live up to stakeholders' expectations. While developing this capacity may seem undeniably desirable, living up to stakeholders' expectations may, perversely, minimize critical scrutiny of, or maximise opportunism relating to, the corporation's practices and what corporate secrets are sanctioned and/or unsanctioned (Schnackenberg and Tomlinson, 2016). Further, transparency in the leadership context, for example, might raise the issue of whether a workforce wants transparent leaders or, instead, leaders who operate with a clear purpose, who are capable of creating a culture worth belonging to, in a work situation that to the employees makes sense. These leadership attributes might not contradict the value of transparency: while such employees may want transparency in their corporations, they attribute greater importance to their leaders acting in a meaningful and responsible way according the values and projects with which they as employees can align.

Whistleblowing.. the new transparency?

Five years after historic NSA leaks, whistleblower tells the Guardian he has no regrets

Edward Snowden has no regrets five years on from leaking the biggest cache of top-secret documents in history. He is wanted by the US. He is in exile in Russia. But he is satisfied with the way his revelations of mass surveillance have rocked governments, intelligence agencies and major internet companies. The most important change, he said, was public awareness. "The government and the corporate sector preyed on our ignorance. But now 
we know. People are aware now. People are still powerless to stop it but we are trying. The revelations made the fight more even."

https://www.theguardian.com/us-news/2018/jun/04/edward-snowden-people-stillpowerless-but-aware (Accessed May 29 2019).

\section{Information, communication and power}

As cited earlier, Schnackenberg and Tomlinson (2016) observed that in the context of disclosure most conceptualizations of transparency involve intentionally shared information. The idea of sharing information assumes implicitly that the same views and understanding of the world are universally held. Cultural studies have shown that this is a naïve assumption, as noted by Mackie (1990), so that avoiding potential misunderstandings that might affect the corporate image, reputation, or brand value is problematic. Consequently, corporations are pressured - through the moral imperative of transparency - to communicate in a simple way where all complexity is reduced so as to provide the information in an accessible form. Luhmann (1999) showed in his theory of systems that each social system (i.e. juridical, economic, political, and so on) communicates by reducing complexity, for example, by using simple dichotomies such as right versus wrong, powerful versus powerless. These reductions can easily lead instead to misunderstandings - especially when the reductions disclose crucial information which is distorted due to differences between the receiver's and the sender's perceptions and interpretations. Such misunderstandings can perpetuate, according to Luhmann, until the information ultimately can be presented in an understandable way, which often happens in relation to strategic concerns such as time and cost. For this reason, Luhmann places trust as an element in the communicative process because, as we argued in Chapter 2, neither the sender nor the receiver can have complete knowledge about everything. Trust becomes crucial when the amount of information grows; however, this is not blind trust but a flexible confidence in the other. When transparency is the norm, trust is minimized for both the sender and the receiver; the sender is not trusted because of the call for transparency and, similarly, the receiver is not trusted to understand information that diverges from the receiver's expectations.

Transparency is also viewed as a social process involving communication and mediation rather than focusing solely on the transmission of information. This perspective is useful in thinking about what happens when organisations disclose information. It can be seen as a process that includes components of subjects that are involved in politically motivated interpretations and 
enactments of transparency, material objects at work in transparency projects that actively mediate and manage the resulting visibilities, and settings which are the loci of transparency projects such as transnational institutions or virtual networked organisations. These components, each complex in themselves, are indicated from research to be entangled in socio-material practices able to modify whatever they seek to make visible or transparent. Transparency is thus theorised as a social process with generative capacities, producing new relationships, understandings and phenomena by virtue of being an assemblage of normativity that mobilises actors to respond in certain ways. Thus, consistent with Beauvoir, theorising transparency as a flow of plentiful and timely information is criticised as being too simplistic and may provide only a partial understanding of the phenomenon.

It is also important to distinguish between more versus better information, as well as to acknowledge that information typically is distributed asymmetrically (Braendle and Noll, 2005). Useful information, as defined by Bateson (1979, p. 5) "is a difference that makes a difference", where the question is not quantity, but relevance and value. Furthermore, knowledge is part of a power-relationship that defines the terms under which it is shared, with whom, in what form, and for what reason. Knowledge is embedded in such power-structures, whether between managers and employees, or the corporation and its stakeholders. Because information, and potentially, knowledge is conveyed through transparency, it thus also operates under the mantle of power.

Loveluck (2015, p. V) attested that "a considerable amount of research has already been directed at understanding the rationale of the information and communication society. Its sometimes distant origins have been explored extensively in order to uncover an underlying ideology, doxa, utopia-a "religion" even. In much the same way as the concept of transparency has been promoted, these analyses have drawn attention to the non-critical and doctrinal way in which information and communication are presented as providing solutions for improving social organisation. Attention has thus been drawn to implicit or explicit political dimensions of the information society, or "information capitalism", according to Loveluck, who contended "that these discourses and representations are firmly associated with "neoliberalism"...which emerged prior to the Second World War but truly gained momentum during the liberal-conservative revolutions of the late 1970s" (ibid.). He argued further that "from this perspective, the development of information and communication technologies has, 
above all, served economic policies of market deregulation, privatization of public services, and the growth of finance and free trade" (ibid.).

\footnotetext{
Seeing like the market; exploring the mutual rise of transparency and accounting in transnational economic and market governance

Mehrpouya, A., Salles-Djelic, M-L. (2019). Accounting, Organizations and Society.

"The shift to transparency in global governance has been shown to have been heavily influenced by the rise of various private actors including the Big Four accounting firms as powerful global actors (Suddaby et al., 2007)... Such reliance on transparency in the name of various publics (increasingly imagined as investors) and their imagined actorhoods, has led to the side-lining and weakening of state-led regulation of economic actors (Merino \& Neimark, 1982)".
}

Loveluck asserted in his paper regarding the advent of hackers concerning the debate surrounding intellectual property and protection of privacy of information, that one of their main maxims "is that the obfuscation of private communications, together with transparency of information of public interest (including private enterprises), is the only way to rebalance power between the government (or monopolistic companies working in collusion with it) and individuals - in accordance with the motto: "privacy for the weak and transparency for the powerful" (p. XV). This is demonstrated in the worthy but illusory efforts of Access Info Europe (Chapter 2 case example). For this reason information capitalism represents not only surveillance of the citizens but also transforms them into passive consumers with "likeable" or "good" behaviours that serves to concentrate ever-growing power in the hands of the technology giants like Google.

Information may manipulate, knowledge may emancipate. The power associated with information is mainly derived from the consideration of information and knowledge as being interchangeable in the common use. Information as power has unique qualities: it can generated at very low cost (it costs nothing to move it around), it is an infinite resource, and has extended usefulness. Disclosure empowers the company to produce a favourable corporate image against which it will be publicly judged or evaluated, even if at the same time it conceals a "hidden shame".

\section{Disclosure and self-judgment}

Sartre expressed shame as an inability to be true to oneself, or as being inauthentic. Viewing oneself as powerless to act according to one's own free will brings a sense of bad faith. Shame, 
in this sense, is the impossibility of being honest or acting in accordance with one's own values. This can be illustrated by a hypothetical example where a medical doctor is forced by a rigid time-management protocol to see a specific number of patients per day, regardless of their problems or illnesses. The doctor may be transparent about reaching his or her objectives but feel ashamed (in Sartre's sense) or guilty about not living up to the Hippocratic ideals of the medical profession where each particular patient or situation should be treated with proper care but where to do so might contravene the imposed managerial performance objectives.

Transparency in this instance might prevent an important debate about professionalism and what is required to deliver a good service. Similarly, shame in Sartre's sense may occur when a corporation is forced to make decisions based on regulatory guidelines that it may not see as relevant to, or appropriate for, their business but which it cannot afford to breach (Janning, 2015). For example, companies in chocolate industries are forced to use a certain detergent to clean their machinery even though they know that its use could ultimately be harmful for human beings. Here, transparency - acting (inauthentically) according to what makes sense economically and following industry rules - is more important than acting truly (authentically).

A project developed by Volans and the Global Reporting Initiative

The transparent economy: Six tigers stalk the global recovery-and how to tame them

"What is the future for sustainability-sometimes called 'non-' or 'extra-financial'reporting? This is the question addressed in The Transparent Economy, the product of a project developed by Volans and the Global Reporting Initiative (GRI). The task: to begin looking out to the year 2020, analysing the trends that will drive or constrain greater transparency and accountability. The study included an online survey of the GRI community, focusing on seven major trends-subsequently boiled down to the TIGERS agenda (Traceability, Integrated Reporting, Government Leadership, Environmental Boundaries, Rating and Ranking, and Shadow Economies). Recommendations are made for business, financial institutions, governments and individuals."

https://www.globalreporting.org/resourcelibrary/Explorations_TheTransparentEconomy. pdf (Accessed May 26 2019).

Shame can be seen as the other side of transparency. It is easy to say "privacy for the weak and transparency for the powerful" (as cited above from Loveluck). The weak, in today's achievement society are those who lack prestige, status and power, those who do not hold the so-called "right" values, according to current social morals. The weak can also include 
people without work, those who smoke tobacco, drink or suffer from excess weight; it can be those who break down due to the pressure of today's society, although those who return from stress or burnout often are considered heroes (Janning, 2017a). Only the so-called strong can afford to be transparent. This is especially so since there is no shame in being inauthentic. This notion concords with neoliberalism where status and prestige are easily identified and related to economic power.

The core of the problem with transparency, therefore, is as Deleuze $(2002$, p. 35) argued in saying that we "have opposed knowledge of life in order to judge life, in order to make it something blameworthy, responsible or erroneous." Instead of being committed to, and engaged in, the challenges and possibilities presented by each situation, as Badiou proposed, life (or the particular situation) is evaluated according to transcendental ideals regarding a sphere outside of life (e.g. Plato's world of ideas). As averred by Badiou, ethical decisionmaking concerns the limits of our current knowledge and, as such, the possibilities for addressing moral dilemmas are constrained. It is for this reason that corporations can act responsibly in that they respond to what is actually occurring rather than merely complying with certain ideals. A corporation that cannot be held to account as responsible for its own actions according to its own conscience (rather than to some externally imposed ideal) cannot be regarded as ethical.

Transparency places greater emphasis on judging, or evaluating existing organisational processes than on assessment of (self-)learning processes based on what actually takes place when corporations make decisions. Since no corporation can be (fully) transparent about everything, it will lend itself constantly to negative judgment as being not sufficiently transparent, especially when matters come to light at a later time which are judged negatively by society. Examples abound where corporations have found themselves on the wrong side of responsible decision making, resulting in scandals and tragedies usually relating to avoidable harm; such as the James Hardie and Johnson and Johnson asbestos cases and the claims for compensation for sufferers of mesothelioma; Union Carbide and the Bhopal disaster in India; BP and the Deepwater Horizon oil spill in the Gulf of Mexico; or the Chinese infant milk tragedy where milk formula was laced with melamine; and many more. The social need for increased transparency clearly reflects a social lack of confidence in, or mistrust of, companies because of their irresponsible behaviour driven by the capitalist cult of profit 
maximisation. Paradoxically, society, or more specifically, stakeholders, through regulators, expect corporations to act responsibly by following particular social guidelines, rather than being judges of their own behaviour.

Viewed in existential terms, a corporation might conform in an outwardly transparent way to a particular corporate image according to the wishes and expectations of dominant stakeholders, rather than align with the intention of transparency for its own sake. Thus, the corporation shifts its responsibility for its actions away from itself and onto another - the stakeholders - according to the moral baseline defined by that other, rather than taking that responsibility upon itself. This does not necessarily imply irresponsible corporate behaviour: most social moral baselines make good sense. However, as we have argued in this chapter, such moral baselines are built on past experience, vary geographically, and are seldom judged by an impartial third party. These baselines are also subject to power struggles and dominant thinking, generating moral codes and practices established and agreed to by activist lobby groups or stakeholders who have a specific interest in the company's performance outcomes. We advocate viewing attention (as discussed earlier in this chapter in relation to Badiou and Simon) as more than a scarce resource: it can be developed so as to build a capacity for deepening and enriching experience. Corporations become morally more conscious by enrolling themselves into moral reasoning and ethical questioning. This can take place in what Aristotle referred to in Ethics, as "noble leisure"; what Han (2015) philosophised as the time of "non-doing," or "a peace time"; or what Deleuze and Guattari (1994) called "interveningtime". The concept of "non-doing" also resembles elements of mindfulness in that there is no need for constant action, allowing things to unfold at their own pace, to adjust to the rhythm of life (Janning, 2017b). Such a space can be the antidote to the obsession with transparency in our current control society, where people and corporations - often unconsciously - are coerced into participating in continuous, ongoing, positive communication.

The following case study illustrates the problem with transparency when there is a semblance of openness about a corporation's decisions and performance, yet all is not what it seems. In this case the publicly listed company met the regulatory requirements for disclosure and reporting so that over its history investors supposedly had an informed view of the performance of their investment. However, the true position was concealed over many years. In this case questions arise regarding board competence and intellectual honesty, as well as 
issues of responsibility and accountability, which were not averted by - or may even have been exacerbated by - a full disclosure regime. It is a case in which Sartre's shame and guilt is exemplified by the board of directors chaired by a former prime minister whose high status and public profile may have fended off questions that could otherwise have been asked about competence and capability as a director and board leader, in favour of the prestige and reputational value such a person could be thought to bestow on a corporation. The major questions, however, are whose real interests in this instance ultimately were served: the board of directors, employees who lost their jobs, sub-contractors whose businesses were jeopardised or that failed as a consequence, the community that would benefit from the completed construction projects, the investors, or wider society? And to what extent has a transparency regime facilitated corporate trustworthiness? This latter question is the focus of the discussion in the next chapter. 


\section{Case example. Chapter 3}

\section{The Demise of Mainzeal: Anatomy of a Corporate Downfall}

This story is the anatomy of the collapse of a New Zealand publicly listed construction company. Notable in this widely publicised High Court case is the statement by the former prime minister who chaired the board that there was openness between the company and its parent - but this was patently unsupported by any legal formality - so much for transparency! As one headline stated, it is a big deal when a former prime minister is found guilty by the High Court.

At the time of its demise, Mainzeal was held by Richina Global Real Estate which was part of Richina Inc, an independent and closely held New Zealand-headquartered Asia Pacific holding company. Mainzeal Property and Construction Ltd was one New Zealand's leading property and construction companies until being placed into receivership and then into liquidation in February 2013, owing creditors $\$ 110$ million.

Mainzeal had been involved in delivering US\$7.5 billion of construction projects across New Zealand and employed more than 500 people. The company was founded in 1968 as a branch of Mainline Corporation Ltd, an Australian company, to develop harbour-front land in downtown Auckland, New Zealand, as part of Mainline-Dillingham-Fletcher. Mainline Contractors Pty Ltd was established from this base and in 1969, became Mainline Corporation of New Zealand, a publicly listed New Zealand company, adopting the name Mainzeal Corporation Ltd in 1975. In 2006 Mainzeal experienced some financial setbacks, posting large losses associated mainly with three large apartment developments in Auckland and a 12,200-seat Arena. However, the losses on these projects were recovered, with Mainzeal's pre-tax earnings reaching a US\$1.6 million surplus compared to a US\$2.8 million loss in the previous year. Following the Christchurch earthquake in 2010 Mainzeal was appointed by insurance company, Vero, as their preferred partner in a joint venture, in their efforts to rebuild Canterbury. In 2011 Mainzeal expanded its services to include facilities management and entered the residential market with a division called Mainzeal Living.

The Richina holding company was created when Mainzeal acquired (and subsequently sold) a New Zealand leather business. In 1996 it changed its name to Richina Pacific (retaining the Mainzeal name for its construction unit) and began investing in China, where its owners saw major business opportunities. Richina Pacific delisted from NZX in January 2009 and went into provisional liquidation in 2013 , handing over its financial statements to the Companies Registrar for the financial years leading up to its demise. The financial reporting obligations of the Mainzeal and Richina group of companies, were murky due to various amalgamations and restructures leading up to its ultimate collapse. The 
registrar decided the only entity in the group obliged to file financial statements was Richina Pacific, which arose because the company was an issuer. It was initially registered as a local company, but later relocated to Bermuda, moving to the overseas company register.

Mainzeal, it turned out, had been propped up like a sad puppet, taking advantage of clients' cash before it paid it out to workers, kept afloat when really it should have collapsed years before it did, in 2013. But few people knew the full extent of its problems, at least not until issues were laid bare on 1 March 2019 when the 178-page High Court decision was released. It told a story of withheld money, a lame business, leaky buildings, broken promises, false hopes and all-round corporate ineptitude which resulted in the Court making a \$36 million ruling for reckless trading against four of the company's five directors.

The judge described how the company, once said to have been New Zealand's third largest construction company, traded while insolvent for several years. It had an annual turnover of $\$ 270 \mathrm{~m}$ $\$ 380 \mathrm{~m}$, and used that cash flow from clients to its advantage before handing it to subcontractors.

The judge said Mainzeal was milked by parent Richina Pacific to buy lucrative assets in China, and told it would be supported, but was given little cash to back that up. By 2009 Mainzeal had loaned Richina $\$ 42 \mathrm{~m}$, meaning the company was insolvent and had been since 2005 .

"At the heart of the plaintiff's reckless trading claims," the judge said of the action brought by the liquidators against the directors, "is the allegation the company was insolvent as a consequence of the Richina Pacific group extracting considerable funds from Mainzeal for investment in China. Mainzeal nevertheless continued trading in an insolvent state for years." The ruling referred to the Mainzeal directors being told by the Richina group about how the money would flow one day. "Directors relied on promises from the Richina Pacific group that financial support would be provided when needed."

A new director appointed to the Mainzeal board a year before its collapse raised questions early on, but Dame Jenny Shipley (the former prime minister) and the other directors rejected allegations that the company was insolvent, or that they had acted unreasonably in relying on Richina's support for the company to stay afloat. Yet those directors had nothing in writing - no contracts giving guarantees, nothing formal or legally binding. What were they thinking? The new director joined the board only in 2012, a year before the collapse, and "almost immediately ... identified the significant underlying issues," the judge said. Without Chinese support, the director realised, Mainzeal would go under and it needed a significant cash injection - specifically, $\$ 20 \mathrm{~m}$ as preference share capital or subordinated debt.

From Richina Pacific's side, stringent Chinese foreign exchange restrictions limited Richina's ability to fulfil its promises. So how did Mainzeal limp on? Belief in the Richina promise and a quirk in the New 
Zealand construction sector which allowed Mainzeal to use a rich cash flow. Time was on its side. Then, time ran out.

Mainzeal's clients paid it for work by the subcontractors and the company retained that cash to keep itself afloat, "effectively using this money as its working capital", in the words of the judgment. At the same time Richina Pacific was using Mainzeal as its own cash cow, "extracting more funds for the benefit of the group from Mainzeal than was recorded in the audited annual accounts", the decision said. "Richina Pacific had extracted considerable funds from Mainzeal. This had been done to help secure assets of considerable value in China," the judge said. These transactions were completed via loans which were recorded as assets on Mainzeal's books.

But at times, Richina was also generous. For example, the judge noted how a developer could not complete a commercial block in the Capital City, Wellington, so Richina paid $\$ 37.4 \mathrm{~m}$ to Mainzeal so it could finish the project, then sell it at a profit. The money was returned to Richina in the form of loans. Richina also supported Mainzeal by guaranteeing money for construction bonds so it could win work, and sometimes it even put up the entire bond, the judge said.

Mainzeal's demise could be traced back to 2004 and 2005, when capital was extracted from the company for Richina Pacific to buy assets in China, including the Shanghai Leather company, today worth more than US\$700m (\$1 billion). In 2005, Mainzeal recorded a significant operating loss of $\$ 12.1 \mathrm{~m}$, and although it was profitable in 2006 due to the sale of a major completed construction project, it lost money in subsequent years. In 2009, former Prime Minister Shipley resigned from the Richina board but kept her Mainzeal directorship. That same year, the judge noted, the company was insolvent, with negative equity of $\$ 44.8 \mathrm{~m}$.

By 2012, Mainzeal had building weather-tightness liability provisions to address, at a crippling $\$ 21.8 \mathrm{~m}$. But the company had another monster in its midst called the Siemens contract, where payments were withheld for work under dispute. During 2012, Mainzeal experienced cash flow problems, mainly due to issues with Siemens, the company contracted to upgrade the country's electricity link between the North and South Islands. That upgrade required work at each end of the link and Mainzeal won the job. The company's PwC auditor told the court of his "considerable concerns" about Mainzeal and how he lost confidence relying on Richina's assurances. The auditor was grateful when PwC lost the company as an audit client. Shipley knew of PwC's scrutiny and acknowledged there was "no question that Mainzeal was reliant on its parent in balance sheet terms". Richina was "open and clear with Mainzeal directors", she said, and spoke in the Court of their support. But there was an absence of relevant letters of support from any Richina entity for the benefit of Mainzeal, and due to a restructuring, Mainzeal was no longer a wholly owned subsidiary of Richina Pacific. The ex-Mainzeal 
chief executive and fellow director was also unconcerned about balance sheet solvency at the time, "because Mainzeal always had the cash flow to pay its debts".

The ruling by the High Court of $\$ 36$ million against three of the four Mainzeal directors and the director of Richina Pacific is the highest amount awarded in New Zealand for reckless trading.

Sourced from:

"Mainzeal: Anatomy of a corporate downfall" Anne Gibson, NZ Herald, 1 Mar 2019. https://www.nzherald.co.nz/business/news/article.cfm?c id=3\&objectid=12208241 (Accessed 15 Mar 2019).

"How Mainzeal collapsed and tarnished a former PM's reputation" Rob Stock, Stuff, Feb 262019. https://www.stuff.co.nz/business/110867141/sinking-shipley-how-mainzeal-collapsed-andtarnished-a-former-pms-reputation (Accessed 15 Mar 2019).

"The Mainzeal collapse and what could've been done differently" Duncan Cotterill, https://duncancotterill.com/publications/the-mainzeal-collapse-and-what-couldve-beendone-differently (Accessed 15 Mar 2019). 


\section{References Chapter 3}

Albu, O. B., \& Flyverbom, M. (2019). Organizational Transparency: Conceptualizations, Conditions, and Consequences. Business \& Society, 58(2), 268297. https://doi.org/10.1177/0007650316659851

Arsov, S. Bucevska, V. (2017). Determinants of transparency and disclosure - evidence from post-transition economies, Economic Research-Ekonomska Istraživanja, 30:1, 745-760.

Badiou, A. (2002). Ethics. An Essay on the Understanding of Evil. Translated and introduced by Peter Hallward. Verso.

Bandsuch, M., Pate, L., This, J. (2008). Rebuilding Stakeholder Trust in Business: An Examination of Principle-Centered Leadership and Organizational Transparency in Corporate Governance. Business and Society Review, 113(1): 99-127.

Bateson, G. (1979). Mind and Nature. A Necessary Unity. Bantam Books.

Baume, S. and Papadopoulos, Y. (2018). Transparency: from Bentham's inventory of virtuous effects to contemporary evidence-based scepticism. Critical Review of International Social and Political Philosophy, 21 (2):169-192.

Bloomfield, R., \& O'Hara, M. (1999). Market transparency: who wins and who loses?The Review of Financial Studies, 12(1), 5-35.

Borgia, F. (2005). Corporate governance \& transparency role of disclosure: how prevent new financial scandals and crimes? Working paper, American University Transnational Crime And Corruption Center (TRACCC), School Of International Service. 59p. http://citeseerx.ist.psu.edu/viewdoc/download?doi=10.1.1.457.722\&rep=rep1\&type= $\underline{\mathrm{pdf}}$

Braendle, U.C., \& Noll, J. (2005). A fig leaf for the naked corporation. Journal of Management and Governance, 9,79-99.

Bushman, R., Chen, Q., Engel, E., \& Smith, A. (2004). Financial accounting information, organizational complexity and corporate governance systems. Journal of Accounting and Economics,37, 167-201.

Christensen, L. T., \& Cheney, G. (2015). Peering into transparency: challenging ideals, proxies, and organizational practices. Communication Theory,25(1), 70-90.

Deleuze, G. (2002). Nietzsche and Philosophy. Translated by Hugh Tomlinson. Continuum.

Deleuze, G. \& Guattari, F. (1987). A Thousand Plateaus. Capitalism and Schizophrenia. Translation and foreword by Brian Massumi. The University of Minnesota.

Deleuze, G. \& Guattari, F. (1994). What Is Philosophy?. Translated by Hugh Tomlinson and Graham Burchell. Columbia University Press.

Dickson, M. A. and Eckman, M. (2008). Media portrayal of voluntary public reporting about corporate social responsibility performance: does coverage encourage or discourage ethical management. Journal of Business Ethics 83, 725-743.

Doorey, D. J. (2011). the transparent supply chain: from resistance to implementation at Nike and Levi-Strauss. Journal of Business Ethics. 103(4), 587-603. 
Farvaque, É., Refait-Alexandre, C. \& Saïdane, D. (2011). Corporate disclosure: a review of its (direct and indirect) benefits and costs. Economie internationale, 128(4), 5-31. https://www.cairn.info/revue-economie-internationale-2011-4-page-5.htm.

Fernandez Feijo, B., Romero, S., \& Ruiz, S. (2014). Effect of stakeholders' pressure on transparency of sustainability reports within the GRI framework. Journal of Business Ethics, $122,53-63$.

Finel, B. I., \& Lord, K. M. (1999). The surprising logic of transparency, International Studies Quarterly.43(2), 315-339.

Frostenson, M., Helin, S., \& Sandström, J. (2011). Organising corporate responsibility communication through filtration: a study of web communication patterns in swedish retail. Journal of Business Ethics, 100(1), 31-43.

Fung, B. (2014). The Demand and Need for Transparency and Disclosure in Corporate Governance. Universal Journal of Management, 2(2): 72-80. http://www.hrpub.org/download/20140105/UJM3-12101630.pdf

Graafland, J. J., Eijffinger, S. C. W., \& Smid, J. H. (2004). Benchmarking of corporate social responsibility: methodological problems and robustness. Journal of Business Ethics. 53(1-2), 137-152.

Griffin, P.A., Sun, E.Y. (2013). Going Green: Market Reaction to CSR Newswire Releases (January 29, 2012). Journal of Accounting and Public Policy, 32(2). Available at SSRN: https://ssrn.com/abstract=1995132.

Halter, M. V., Coutinho de Arruda M. C., \& Halter, R. B. (2009). Transparency to reduce corruption? dropping hints for private organizations in Brazil. Journal of Business Ethics. 84(3), 373-385.

Han, B-C. (2015). The Transparency Society. Translated by Erik Butler. Stanford University Press.

Han, B-C.(2018). Saving beauty. Translated by Daniel Steuer. Polity.

Janning, F. (2015).Towards an immanent business ethics?Asian Journal of Humanities and Social Studies, 3(6), 492-500.

Janning, F. (2017a). The Happiness of Burnout. Koenig Books.

Janning, F. (2017b). A Philosophy of Mindfulness. A Journey with Deleuze. NFB/Amelia Press.

Kabat-Zinn, J. (2013). Full Catastrophe Living. Piatkus.

Loveluck, B. (2015). Internet, une société contre l'État : Libéralisme informationnel et économies politiques de l'auto-organisation en régime numérique. Réseaux, 192(4): 235-270. https://www.cairn.info/revue-reseaux-2015-4-page-235.htm.

Luhmann, N. (1999). Tillid. En mekanisme til reduktion af social kompleksitet. Hans Reitzels Forlag.

Mackie, J. L. (1990). Ethics: inventing right and wrong. Penguin Books.

Madhavan, A., Porter, D. C., \& Weaver, D. G. (2005). Should securities markets be transparent?Journal of Financial Markets, 8(3), 265-287. 
Parsons, C. (2019). The (In)effectiveness of Voluntarily Produced Transparency Reports. Business \& Society, 58(1), 103-131. https://doi.org/10.1177/0007650317717957

Polanyi, M. (2009). The tacit dimension. University of Chicago Press.

Schnackenberg, A. K., \& Tomlinson, E. C. (2016).Organizational transparency a new perspective on managing trust in organization-stakeholder relationships.Journal of Management, 42(7), 1784-1810.

Simon, H. A. (1971). Designing Organizations for an Information-Rich World. Computers, Communication, and Public Interest, 40-41. John Hopkins University Press.

Williams, C. C. (2008). Toward a taxonomy of corporate reporting strategies. International Journal of Business Communication, 45(3), 232-264. 